\title{
Hallazgo casual en estudio de extensión de adenocarcinoma de próstata.
} Rincón Mayans A*, Rosell Costa D*, Benito Boillos A**, Zudaire Díaz-Tejeiro B**, Rioja Zuazu J*,
Tolosa Eizaguirre E.*

*Departamento Urología y ${ }^{* *}$ Radiodiagnóstico. Clinica Universidad de Navarra.

Actas Urol Esp. 2007;31(6):696

$\mathrm{P}$ aciente de 52 años, con antecedentes familiares de padre fallecido de adenocarcinoma de próstata, se realiza determinación de PSA con resultado de $6 \mathrm{ng} / \mathrm{ml}$. Se indica biopsia de próstata con resultado anatomopatológico de adenocarcinoma de próstata Gleason $3+3$. Para completar el estudio de extensión se realiza resonancia magnética pélvica.

En RMN no se observan signos de extensión neoplásica extraprostática, afectación de las vesículas seminales o adenopatías pélvicas o retroperitoneales sospechosas desde el punto de vista radiológico. Se informa de formación quística prostática central de $2,6 \mathrm{~cm}$ compatible con quiste del utrículo (flechas).

En el varón, la desaparición del conducto de Müller ocurre a las 7 semanas, antes de que se evidencien las células de Leydig y se debe a la sintesis, por parte de las células de Sertoli, de una sustancia denominada MIS (sustancia inhibidora de Müller) que produce involución del conducto de Müller, del que queda como vestigio más evidente el utrículo prostático.

Se trata de una patología cuyo diagnóstico es raro y que gracias a la gran difusión de las pruebas de imagen abdomino-pélvicas veremos con mayor frecuencia.

Correspondencia autor: Dr. A. Rincón Mayans Departamento de Urología

Clínica Universitaria de Navarra

E-mail autor: arincon@unav.es

Información artículo: Imágenes en Urología

Trabajo recibido: abril 2007

Trabajo aceptado: mayo 2007

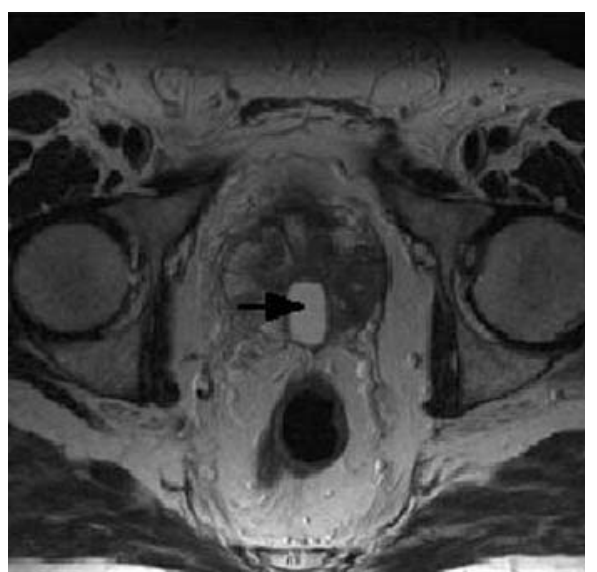

FIGURA 1

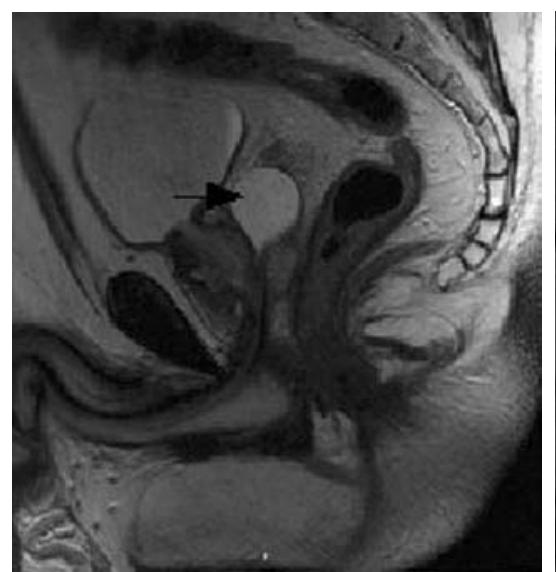

FIGURA 2

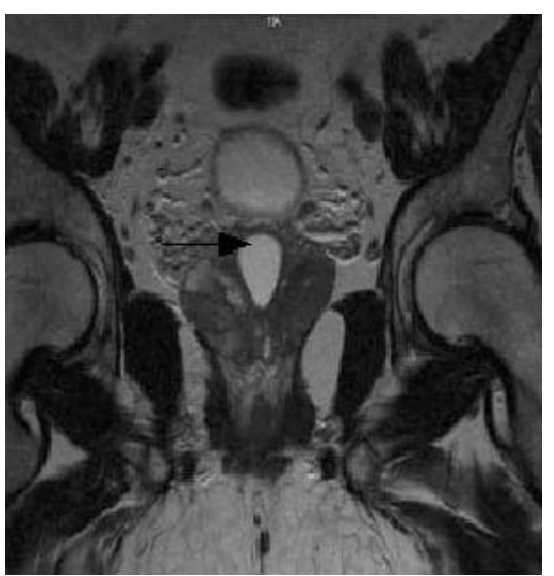

FIGURA 3 